\author{
Volume 6 No 1 September 2020 \\ p-ISSN: 2460-8750 e-ISSN: 2615-1731 \\ https://doi.org/10.26858/talenta.v6i1.14532
}

\title{
PERAN POLA ASUH ORANG TUA DALAM MEMBENTUK KONSEP DIRI PADA ANAK
}

\author{
Afida Vona ${ }^{1 *}$, Koryna Aviory ${ }^{2}$ \\ ${ }^{12}$ Fakultas Keguruan dan Ilmu Pendidikan, Universitas PGRI Yogyakarta. Indonesia \\ Email: afidavona0@gmail.com ${ }^{1}$ aviory_koryna@gmail.com²
}

(C2018 -JPT Fakultas Psikologi Universitas Negeri Makassar. Ini adalah artikel dengan akses terbuka di bawah licenci CC BY-NC-4.0 (https://creativecommons.org/licenses/by-nc/4.0/ ).

\begin{abstract}
The purpose of this article is to describe the role of parents in parenting to shape the child's self-concept. The method applied is literature study or commonly known as literature study. This paper is derived from the ideas or views of journal authors and books in accordance with the discussion. Data analysis is the reading sources are compiled, analyzed, then the final result is concluded. The results of this study explain that parenting parents really need to be learned let alone understood by parents wherever they are, because it greatly influences the form of the child's self-concept. Positive education, as directed, is given understanding, advised so that children can correct their mistakes, allowing the growth of positive self-concepts in children For example the child is able to adjust quickly, confidently, willing to try and dare to make decisions. This is known as democratic parenting. But on the contrary, bad education from parents, such as often scolding when children make mistakes or fail (applying authoritarian parenting) allows the embedded negative self-concept in children. Negative self-concept is synonymous with self-doubt, fear of determining decisions, and minimal adaptability.
\end{abstract}

Keywords: Parenting Parents; Self Concept

\begin{abstract}
ABSTRAK
Tujuan artikel ini yaitu menggambarkan peranan orang tua dalam mengasuh sang anak hingga terbentuk konsep dirinya. Metode yang diterapkan yaitu kajian kepustakaan atau biasa dikenal dengan studi literatur. Analisis data yaitu sumber-sumber bacaan dikompulasi, dianalisis, lalu disimpulkan hasil akhirnya. Hasil dari kajian ini menjelaskan bahwa pola asuh orang tua sangat perlu untuk dipelajari apalagi dipahami oleh orang tua dimanapun berada, karena sangat mempengaruhi bentuk konsep diri sang anak. Didikan yang positif, seperti diarahkan, diberi pengertian, dinasehatkan hingga anak bisa memperbaiki kesalahanya, memungkinkan terbentuknya pembawaan/konsep yang positif pada anak Misalnya sang anak mampu penyesuaian dirinya cepat, percaya diri, mau mencoba dan berani menentukan keputusan. Ini dikenal dengan pola asuh yang demokratis. Tapi sebaliknya, didikan tidak baik dari orang tua, seperti sering memberi cacian saat anak melakukan kesalahan atau gagal (menerapkan pola asuh otoriter) memungkinkan terbentuknya pembawaan/konsep yang negatif pada anak. Misalnya identik dengan meragukan diri sendiri, takut menentukan keputusan, serta kemampuan adaptasi yang minim.
\end{abstract}

Kata Kunci: Pola Asuh Orang Tua, Konsep Diri

\section{PENDAHULUAN}


Manusia dalam menjalani kehidupan akan selalu dihadapkan dengan hambatan. Menurut pendapat (Setiawati, 2011) hambatan merupakan hal yang membuat suatu hal menjadi terganggu atau bisa dikatakan tidak terlaksana dengan baik. Hambatan tersebut dapat bersumber dari dalam diri sendiri. Membuat diri sulit untuk mencapai apa yang sesungguhnya diharapkan dalam hidup. Setiap individu memiliki keinginan untuk maju namun untuk beberapa orang memiliki hambatan untuk keinginan tersebut. Individu cenderung merasa bahwa harapan yang dimiliki sulit untuk diwujudkan, terlalu berlebihan memikirkan sulitnya, begitu memikirkan pandangan orang lain, dan sebagainya.

Pikiran negatif seperti yang telah disebutkan di atas sesungguhnya amat merugikan, membuat hati ragu untuk menjemput banyaknya peluang yang ada. Seseorang takut dalam mengambil keputusan, tidak siap jika gagal, bermental lemah. Salah satu penyebabnya adalah telah terpupuknya konsep diri negatif dalam diri. Konsep pengintegrasian kepribadian, mengusahakan tingkah laku diri hingga pada akhirnya akan tercapai kesejahteraan diri, semuanya itu dipengaruhi oleh sesuatu yang paling dasar dalam diri kita, yaitu yang biasa dikenal dengan konsep diri. Konsep diri dikenal bukan hanya penggambaran deskripsi tentang diri, melainkan merupakan pandangan individu terkait dirinya sendiri. Bentuk penggambaran diri yang tersusun atas identitas personal dan sosial dalam proses munculnya dapat bergantian ataupun bersamaan. (Efendi \& Rosra, 2011)

Segala yang ada pasti mempunyai lawan dan pasangannya masing-masing, begitu juga konsep diri ini, memiliki dua jenis yang berlawanan, yaitu konsep diri yang positif dan yang negatif. Perlu ditekankan bahwa bukan merupakan kebanggaan besar pada diri jika konsep yang terbentuk dalam diri adalah positif, melainkan lebih berupa menghargai diri sendiri. Memiliki nilai positif dalam konsep dirinya, membuat seseorang mampu dengan baik mengenal dirinya serta amat memberliankan segala sesuatu yang terdapat dalam dirinya. Seseorang mampu bersikap demokratis dalam lingkungan, percaya penuh pada kemampuan diri dan mau mencoba. Akan lebih mampu merencanakan tujuan-tujuan hidup sesuai dengan realita, sehingga lebih besar kemungkinan diri untuk sukses dalam mencapai tujuan hidup tersebut.

Hal yang selalu membuat seseorang terfokus pada segala sesuatu yang berbau negatif dalam dirinya itulah yang disebut konsep diri yang negatif. Seseorang akan sangat susah mengontrol diri dan juga menemukan hal-hal positif yang pantas untuk dihargai dalam hatinya. Maria (Muawanah, 2012) mengatakan bahwa seseorang dengan konsep diri yang negatif sulit sekali percaya dan yakin bahwa dirinya akan mampu mencetak keberhasilan sendiri. Tetapi akan menyatakan bahwa keberhasilan itu terjadi karena bantuan orang lain, dan konsep diri negatif itu pun akan membuat seseorang memiliki kecemasan yang tinggi, lebih mudah menyalahkan diri sendiri karena merasa kurang beruntung dibandingkan dengan orang lain, merasa tidak mampu. Karena itulah, bahayanya konsep diri negatif, akan melarutkan pemikiran positif dan menenggelamkan seseorang di kegagalan. Terlalu sering memikirkan bayang-bayang kegagalan dan kemudian menjadi kenyataan akibat dari menghindari semua kesempatan. Kesempatan yang sebenarnya adalah peluang untuk berkembang lebih luar biasa.

Individu dalam membentuk konsep dirinya, sejak lahir (masa awal perkembangan) seseorang pasti melalui langkah demi langkah dimana lingkungan berperan besa. Sumber utama seseorang dalam membentuk konsep diri adalah interaksinya dengan orang lain. (Subianto, 2013) berpendapat bahwa pendidikan yang pertama diperoleh seseorang adalah dalam keluarganya sendiri. Menurut (Marisa et al., 2018), keluarga merupakan akses utama dalam aktivitas seseorang. Keluarga yang dimaksud disini merupakan orang-orang yang dijadikan prioritas dan lebih awal dikenal dari semenjak kita lahir, yaitu orang tua (ibu beserta ayah). Cara orang tua mendidik amat besar pengaruhnya untuk membentuk konsep diri anak. Sikap mendidik orang tua ini dinamakan pola asuh. (Adawiah, 2017) menjelaskan 
bahwa pola asuhan ibu dan ayah adalah cara mendidik, merawat, memberikan perlakuan kepada sang anak dari masa ke masa (relatif konsisten). Bisa ditanggapi oleh sang anak dari sisi positif ataupun sisi negatif.

Penelitian yang dilakukan Niaraki, dkk., (2013) menunjukkan hasil bahwa pola perilaku orang tua tehadap anak amat mempengaruhi psikologi, harga diri, dan kebermanfaatan hidup sang anak (pada remaja Iran tahun 2012). Begitu juga, Kordi (2010) dalam (Longkutoy et al., 2015) menurut penelitian di Malaysia pada 2010, didapatkan hasil bahwa cara asuh orang tua berdampak besar terhadap prestasi anak. Erlanti dkk (2016) dalam penelitiannya didapat data bahwa tidak semua orang tua punya pengetahuan dan skill yang memadai tentang cara mengasuh dan mengasihi buah hati dengan baik.

Penelitian-penelitian diatas menjelaskan bahwa pola asuh orang tua sangat menentukan nasib anak kedepannya, mempengaruhi segala aspek hidup anak. Pengaruh-pengaruh itu merupakan hal-hal yang harus diperhatikan agar tidak terbawa ke arah negatif. Melalui kajian ini, penulis ingin melakukan pengembangan tentang sesuatu yang sebenarnya adalah sumber dari segala masalah tersebut, mengangkat langsung tentang konsep diri sang anak. Tentunya akan dikaitkan dengan cara didik yang diterapkan orang tua (pola asuh). Maka penulis tertarik untuk mengkaji lebih jauh agar tercapai tujuan untuk mengetahui bagaimana pola asuh orang tua dapat berperan dalam membentuk konsep diri pada anak.

\section{METODE}

Pendekatan kualitatif digunakan dalam kajian ini dengan metodenya berupa kajian kepustakaan (studi literatur). Memanfaatkan informasi dari buku, jurnal, serta literatur lain sebagai sumber utama. Setelah itu, seluruh data yang didapat akan diamati dan di analisis kecocokan serta keakuratannya dengan metode analisis deskriptif. Sehingga hasil analisis dapat sesuai dengan variabel yang dikaji, dapat dituliskan dengan jelas, objektif, runtut, dan kritis. Ruang lingkup penelitian seputar dunia psikologi dengan deskripsi fokus penelitian yaitu tentang peran pola asuh orang tua tentang pembentukan konsep diri pada anak. Peristiwa yang diamati masih diutamakan yang terjadi dalam negeri, dengan sampel yang difokuskan pada anak-anak masa perkembangan awal.

Adapun sumber data dalam kajian ini adalah data sekunder berupa buku, jurnal ilmiah, seminar, dan artikel online. Buku-buku yang dijadikan referensi yaitu buku karya Drs. Syaiful Bahri Djaramah mengenai Guru dan Anak Didik Dalam Interaksi Edukatif, dan buku Harnilawati, H. Tentang Konsep dan proses keperawatan keluarga. Selain itu banyak juga Artikel Online, Artikel Seminar, dan juga Jurnal yang telah terlampir pada daftar pustaka.

\section{HASIL DAN PEMBAHASAN \\ Hasil}

Dari kajian kepustakaan yang penulis lakukan, diperoleh hasil bahwa diantara beberapa tahap pembentukan konsep diri pada anak, tahap terpenting yaitu tahap terbentuknya konsep diri primer (Hendri, 2019). Konsep diri primer anak merupakan hal yang terbentuk dari hasil interaksi dengan keluarga, berhubungan dengan didikan, perlakuan orang tua pada anak (pola asuh), dan tentunya ini menjadi hal yang paling dasar. Hasil interaksi dengan orang tua dalam lingkungan keluarga akan berpengaruh besar terhadap cikal bakal pembawaan seorang anak. Pola asuh orang tua terus berlangsung dari waktu ke waktu. Ibarat tanaman, sang anak terus dipupuk dengan jenis pupuk yang menjadi khas dalam keluarga itu. Jadi, pertumbuhan dan perkembangan kualitasnya ditentukan dengan jenis pupuk tersebut.

Dalam menjalankan perannya terhadap membentuk konsep diri anak, cara asuh yang diterapkan oleh orang tua menurut Suherman (Joni, 2015) dibagi menjadi tiga jenis, yaitu pola asuh otoriter, pola asuh demokratis, dan pola asuh membiarkan atau permisif. (Zainuren, 
2014) menyebutkan bahwa peranan pola asuh orang tua terhadap sang anak yaitu sebagai yang mendidik, memotivasi, dijadikan contoh, dijadikan teman, pengawas, dan membimbing. Sedangkan, peranan orang tua terhadap anaknya yaitu sebagai pedidik, sebagai yang dijadikan contoh, sebagai teman, motivator, pengawas, dan sebagai pembimbing (konselor).

\section{Pembahasan}

Konsep diri adalah cara individu memandang dirinya sendiri dalam segala aspek, berdasarkan pada pengalaman menjalin relasi dengan orang lain. Konsep diri merupakan hal yang begitu penting sebagai pembangun jati diri, penentu sikap diri/kepribadian, hingga jika baik akan tercapai kesehatan mental sesuai dengan yang diharapkan.

Menurut (Halida, 2014) ada dua macam konsep diri, ada yang positif dan ada yang negatif. Konsep diri positif akan menunjukkan kita ke arah sifat yang positif, pandai mengenyampingkan ego, dermawan pada siapa saja, serta rendah hati. Konsep diri positif akan membantu seseorang lebih bijak dalam melangkah, menentukan apa yang harus diambil apa yang tidak dalam setiap keadaan. Sedangkan konsep diri negatif dicerminkan dalam tidakan yang tidak teratur, labil, egois, dan juga pembawaan diri amat kaku.

Individu yang memiliki konsep diri positif akan disenangi oleh banyak orang. Orang lain akan memberikan kesan positif terhadap orang tersebut. Orang lain akan memberikan kesan bahwa orang tersebut mandiri, percaya diri, amat baik. Menurut Efendi dan Rosra (2011) seseorang dengan konsep diri positif masing-masing memiliki pandangan mengenai gambaran dirinya. Keyakinan akan kemampuan diri sendiri sehingga akan terpacu untuk belajar lebih giat. Sebaliknya, seseorang dengan konsep diri yang negatif akan menganggap dirinya sangat lemah, tidak bisa apa-apa, kurang percaya diri, merasa terkendalikan. Demi membentuk konsep diri positif pada anak, maka orang tua wajib memperhatikan bagaimana pola asuh yang sesuai untuk anak agar tidak salah langkah dan menuai hasil maksimal kedepannya.

(Adawiah, 2017) menjelaskan bahwa tanggung jawab orang tua terhadap anaknya berupa tiga hal, yaitu asih, asah, dan asuh. Asih yaitu orang tua mencurahkan kasih dan sayang untuk sang buah hati. Asah yaitu adanya penyaluran bakat dan minat anak. Sedangkan Asuh, orang tua merawat serta mendidik anak hingga anak dapat berkembang seiring jalannya usia. Cara mengasuh yang pas serta sesuai dengan kebutuhan anak akan membuat anak menerima dengan kesan yang positif. (Israfil, 2015) menekankan bahwa pengaruh pola asuh orang tua yaitu mengasah jiwa adaptasi an kemampuan interaksi sang anak dengan lingkungan sekitar sehingga anak dapat lebih mudah bergaul dengan teman-temannya. (Djaramah, 2014) menyatakan bahwa pola asuh orang tua dapat diartikan seluruh komunikasi dan juga interaksi yang terjalin antara anak dan orang tua, di mana dengan bimbingan dan didikan orang tua mampu membentuk tingkah laku dan nilai pengetahuan anak hingga tercipta kepribadian yang baik pada anak. Anak terbentuk dengan matang, harapannya akan menjadi seperti yang orang tua inginkan. Pola asuh orang tua merupakan upaya yang konsisten, dijalankan tetap dari waktu kewaktu.

(Zainuren, 2014) menyebutkan bahwa peran pola asuh orang tua yaitu untuk mendidik, untuk mendorong/memotivasi, untuk memberikan contoh, untuk menjadi teman, untuk mengawasi, dan untuk membimbing. Untuk beberapa peranan diatas, penjelasannya penulis rincikan sebagai berikut: 1 Untuk Mendidik. Tanggung jawab ibu dan ayah sebagai madrasah utama untuk buah hatinya. Pemberian pola asuh yang baik akan memberi bekal ilmu pengetahuan agama, maupun pengetahuan umum yang baik pula, 2. Untuk Mendorong, yakni untuk berkembang, anak amat sangat butuh support dari kedua orang tuanya. kebermanfaatannya adalah anak menjadi pribadi yang lebih berani, serta lebih percaya diri dalam membangun relasi dengan orang lain di lingkungannya, 3. Untuk Memberikan Contoh. 
Pola asuh yang baik yaitu yang memberikan contoh yang baik pula. Setiap tindakan yang dilakukan orang tua akan membekas pada sang anak. Besar kemungkinan anak akan meniru tindakan tersebut. Maka, orang tua perlu berhati-hati, 4. Untuk Menjadi Teman. Pola asuh yang pas akan membuat orang tua seperti teman sendiri bagi anak. Sebagai teman dalam mencurahkan isi hati sang anak, anak akan merasa lebih diberi empati dan dihargai keluh kesahnya. Besar kemungkinan anak akan merasa aman, dipercaya, serta nyaman. Anak juga tak akan ragu menyampaikan apa yang ia rasa, 5. Untuk Mengawasi. Orang tua dalam mengasuh pastilah akan selalu ingin anak berprilaku baik sesuai dengan jalannya. Apalagi lingkungan amat sangat mempengaruhi tumbuh kembang anak. Cemas yang dirasa orang tua amat wajar. Tapi, jangan sampai orang tua mengekang sang anak, karena itu dapat berakibat buruk pada kondisi mentalnya. 6. Untuk Membimbing, pola asuh tak lepas dari sikap membimbing. Peran orang tua adalah memberikan pertimbangan terhadap baik buruknya suatu hal sehingga dapat menghantarkan anak pada keinginan yang terbaik.

Menurut Suherman (Joni, 2015) Pola Asuh Orang Tua dibagi menjadi tiga bentuk, yaitu sebagai berikut:

1. Pola Asuh Otoriter.

Pola asuh ini amat tidak sehat jika diterapkan, apalagi untuk masa-masa perkembangan awal sang anak. Anak akan sering merasa tertekan karena harus selalu dikendalikan oleh kedua orang tuanya. Ini tak baik bagi mentalnya. Jadi, anak sangat terkekang karena kebebasannya sangat dibatasi. Apa yang anak lakukan atau tentukan harus didasarkan pilihan orang tua. Dikuatkan oleh (Harnilawati, 2013) bahwa orang tua dengan pola asuh otoriter ini dapat membuat anak takut, semakin terpuruk, hingga amat membahayakan mental anak (anak bisa mengalami depresi). (Grytina Situmorang, Dr. Maria Susila Sumartiningsih, MPd., MSc., 2015) Pola asuh otoriter juga akan membuat buah hati cemas berlebih. Contoh penerapan pola asuh ini, orang tua cenderung memberikan tanggapan negatif terhadap kesalahan yang diperbuat anak. Tanggapan bisa berupa tindakan, perkataan. Contoh yang berupa perkataan adalah ocehan yang menyebutkan betapa bodohnya sang anak, nakal dan susah diatur, serta kata-kata kasar lainnya yang membuat anak terganggu mentalnya. Akibatnya anak menjadi penakut dan banyak memendam masalahnya sendiri. Orang tua juga kurang memberikan support terhadap hal-hal yang dilakukan anak. Hingga anak merasa kurang dihargai dan pastinya ini juga mengikis psikologinya.

2. Pola Asuh Demokratis

Pola asuh yang satu ini amat menspesialkan anak. Anak sangat diperhatikan kebutuhan sesuai masa perkembangannya. Sang anak sangat dihargai, didukung keinginannya, dibimbing dengan penuh cinta dan pengertian. Sesuai dengan penelitian oleh (McKinney et al., 2011) yang menyatakan bahwa pola asuh orang tua terhadap anak dengan penuh kehangatan, penerimaan, dukungan, dan cinta secara konsisten dalam mengawasi dan mendisiplinkan anak terbukti membuat perkembangan sang anak menjadi positif. Anak tumbuh dengan dengan penuh kehangatan dan mentalnya tak akan terganggu. Anak akan lebih merasa diperhatikan oleh keluarga, merasa penting karena selalu dilibatkan dalam setiap pengambilan keputusan.

Sang anak akan lebih terpupuk keberanian, keterampilan, harga diri, serta kepercayaan dirinya jika dibimbing sepenuh hati dan diberi kepercayaan oleh orang tuanya. Pola asuh semacam ini sangat tepat untuk anak demi membentuk konsep diri yang baik pada anak. Anak akan merasa sangat didukung serta dihargai setiap tindakannya. Anak tidak merasa dibandingkan dengan orang lain, karena orang tua paham bahwa setiap manusia punya kekhasan dan potensi yang berbeda-beda antar satu dengan lainnya. Orang tua juga selalu memberi pengertian pada anak, pengarahan yang jelas, sehingga anak mau memperbaiki dengan ikhlas jika berbuat salah. Dan yang terpenting sang anak mentalnya tidak terganggu dengan stigma-stigma negatif dari orang tua yang membuat dirinya merasa direndahkan. 


\section{Pola Asuh Membiarkan atau Permisif.}

Kebebasan yang berlebihan menjadi ciri khas dari pola asuh ini. Orang tua membiarkan anak berprilaku sesuai keinginan hatinya. Lebih terkesan membiarkan sang anak. Orang tua mengenal anaknya sebagai individu yang memiliki kepribadian bebas, hingga tak perlu adanya perhatian, pengarahan, apalagi bimbingan. Orang tua percaya anak mampu dengan sendirinya. Pola asuh seperti ini juga kurang sesuai jika diterapkan untuk sang anak. Anak butuh dibimbing dan diarahkan, apalagi saat tahap perkembangan di usia awal. Orang tua dalam pola asuh ini bersikap tak peduli terhadap anak hingga berbahaya terhadap kepribadian sang anak, anak cenderung akan lari dari tanggungjawabnya. Pola asuh anak harus benarbenar dengan pertimbangan yang matang sesuai dengan peran pola asuh itu sendiri terhadap konsep diri anak. Sesuai dengan pendapat (Kamila, Karina Megasari Winahyu, 2018) dan hasil penelitian (Abdullah, 2015) serta (Kania Saraswatia et al., 2016) bahwa anak perlu mendapat bimbingan yang penuh dari ayah dan ibunya. Karena, jika asuhan yang diberi baik, maka akan membuat tertanamnya pemikiran dan perilaku yang baik pula pada diri anak.

\section{KESIMPULAN}

Konsep diri amat sangat penting bagi setiap individu. Menjadi pondasi dalam berprilaku maupun berhubungan sosial dengan lingkungannya. Konsep diri ini ada bukan dari faktor bawaan, melainkan dari hasil hubungan sosial dan interaksi dengan banyak orang, terutama lingkungan keluarga (ibu dan ayah). Pola asuh ibu dan ayah terhadap anak sejak usia dini merupakan hal terpenting (utama) untuk membentuk konsep diri anak yang baik dan sesuai dengan yang diharapkan. Sejak usia dini, akan dengan sangat muda menerima apa yang didapat, belum bisa menetukan mana yang baik mana yang buruk. Semua asuhan ibu dan ayah adalah yang terbaik baginya.

Asuhan yang positif dari orang tua pasti menghasilkan konsep diri yang positif pada anak, dan juga sebaliknya jika asuhannya negatif maka negatif pula hasil konsep diri anaknya. Maka, diperlukan kehati-hatian dan perhatian yang lebih dari kedua orang tua mengenai bagaimana pola asuh yang seharusnya diterapkan. Menjalankan peranan ini tidaklah mainmain. Peran yang begitu besar dan dampaknya amat sangat dirasa oleh sang anak. Peran pola asuh orang tua terhadap anaknya sangatlah banyak, yaitu untuk mendidik, untuk mendorong/memotivasi, untuk memberikan contoh, untuk menjadi teman, untuk mengawasi, dan untuk membimbing.

Berdasarkan hasil kajian literatur ini ada rekomendasi yang dapat disampaikan oleh pengkaji yaitu bagi pengkaji selanjutnya dapat mengkaji/meneliti tentang variabel-variabel yang berkesinambungan dan dapat disandingkan dengan konsep diri anak. Sehingga akan didapat informasi yang lebih luas terkait konsep diri anak tersebut.

\section{DAFTAR PUSTAKA}

Abdullah, N. (2015). Hubungan Pola Asuh Orang Tua dengan Konsep Diri Anak Usia Sekolah. Seminar Psikologi \& Kemanusiaan Psychology Forum UMM, 222-225. http://mpsi.umm.ac.id/files/file/222-225 Nurfia abdullah.pdf

Adawiah, R. (2017). Pola asuh orang tua dan implikasinya terhadap pendidikan anak. Jurnal $\begin{array}{lll}\text { Pendidikan Kewarganegaraan, } & 7, & 33-48 .\end{array}$ https://media.neliti.com/media/publications/121261-ID-pola-asuh-orang-tua-danimplikasinya-ter.pdf

Asep Lukman Efendi, Muswardi Rosra, Y. (2011). Hubungan antara konsep diri dalam belajar dan motivasi belajar dengan prestasi akademik mahasiswa. Journal of Chemical Information and Modeling. 
file://C:/Users/User/AppData/Local/Packages/Microsoft.MicrosoftEdge_8wekyb3d8bb we/TempState/Downloads/4569-9714-1-PB (1).pdf

Drs. Syaiful Bahri Djaramah, M. A. (2014). Guru dan anak didik dalam interaksi edukatif. PT. RINEKA CIPTA. https://idr.uin-antasari.ac.id/8868/1/1.pdf

Erlanti, M. S., Mulyana, N., \& Wibowo, H. (2016). Teknik Parenting Dan Pengasuhan Anak Studi Deskriptif Penerapan Teknik Parenting Di Rumah Parenting Yayasan Cahaya Insan Pratama Bandung. Prosiding Penelitian Dan Pengabdian Kepada Masyarakat, 3(2). https://doi.org/10.24198/jppm.v3i2.13686

Grytina Situmorang, Dr. Maria Susila Sumartiningsih, MPd., MSc., P. U. (2015). Literature review: perbedaan pola asuh orang tua yang otoriter, otoritatif \& permisif tehadap perkembangan self esteem pada remaja. Universitas Pelita Harapan, 66-72. http://ejournal.stikesborromeus.ac.id/file/8-10.pdf

Halida. (2014). Analisis konsep diri mahasiswa pada program studi PG-PAUD FKIP UNTAN PONTIANAK. Pendidikan Usia Dini, 8(1), 35-46. https://media.neliti.com/media/publications/117931-ID-analisis-konsep-diri-mahasiswapada-prog.pdf

Harnilawati, H. (2013). Konsep dan proses keperawatan keluarga. Pustaka As Salam. https://books.google.co.id/books?id=Ta3GAwAAQBAJ\&printsec=frontcover\#v=onepag $\mathrm{e} \& \mathrm{q} \& \mathrm{f}=$ false

Hendri. (2019). Peran Pola Asuh Orang Tua Terhadap Pembentukan Konsep Diri Pada Anak. At-TAUJIH, 2(2), 56-71. file:///C:/Users/User/AppData/Local/Temp/6528-15051-1-PB2.pdf

Israfil. (2015). Seminar Psikologi \& Kemanusiaan: Hubungan Pola Asuh Orang Tua Dengan Perkembangan Anak Usia Prasekolah. Psychology Forum UMM, 978-979. http://mpsi.umm.ac.id/files/file/175-179 Israfil.pdf

Joni. (2015). Hubungan Pola Asuh Orang Tua Terhadap Perkembangan Bahasa Anak Prasekolah (3-5 Tahun) Di PAUD Al-Hasanah Tahun 2014 Joni. JURNAL PAUD TAMBUSAI, 1(6), 42-48. file://C:/Users/User/AppData/Local/Temp/54-104-1-SM.pdf

Kamila, Karina Megasari Winahyu, W. D. (2018). Jurnal JKFT : Universitas Muhamadiyah Tangerang Hubungan antara Konsep Diri dan Motivasi Belajar Mahasiswa Keperawatan Tingkat I \& II di Universitas Muhammadiyah Tangerang Oleh Fakultas Ilmu Kesehatan Universitas Muhammadiyah Tangerang Kamila Jurnal JKFT. Jurnal JKFT: Universitas Muhamadiyah Tangerang, 2, 1-6. file:///C:/Users/User/AppData/Local/Packages/Microsoft.MicrosoftEdge_8wekyb3d8bb we/TempState/Downloads/1986-4584-1-SM (3).pdf

Kania Saraswatia, G., Zulpahiyana, Z., \& Arifah, S. (2016). Faktor-Faktor yang Mempengaruhi Konsep Diri Remaja di SMPN 13 Yogyakarta. Jurnal Ners Dan Kebidanan Indonesia, 3(1), 33. https://doi.org/10.21927/jnki.2015.3(1).33-38

Longkutoy, N., Sinolungan, J., \& Opod, H. (2015). Hubungan pola asuh orang tua dengan kepercayaan diri siswa smp kristen ranotongkor kabupaten minahasa. Jurnal EBiomedik, 3(1). https://doi.org/10.35790/ebm.3.1.2015.6612

Marisa, C., Fitriyanti, E., \& Utami, S. (2018). Hubungan Pola Asuh Orangtua dengan Motivasi Belajar Remaja. Jurnal Konseling Dan Pendidikan, 6(1), 25. https://doi.org/10.29210/118700

McKinney, C., Milone, M. C., \& Renk, K. (2011). Parenting and Late Adolescent Emotional Adjustment: Mediating Effects of Discipline and Gender. Child Psychiatry \& Human Development, 42(4), 463-481. https://doi.org/10.1007/s10578-011-0229-2

Muawanah, L. B. (2012). Kematangan emosi, konsep diri dan kenakalan remaja. JURNAL PSIKOLOGI, 7, 490-500. https://doi.org/10.1017/CBO9781107415324.004

Niaraki; Fahimeh Rezai: Rahimi; Hasan. (2013). The impact of authoriative, permissive, and 
authortaian behavior of parents on self-consept, psychological health and life quality. Scholarly Journals, 2(October), 78-85. file:///C:/Users/User/AppData/Local/Temp/24114-2-PB.pdf

Setiawati, E. (2011). Hambatan Epistemologi (Epistemological Obstacles) Dalam Persamaan Kuadrat Pada Siswa Madrasah Aliyah. "Building the Nation Character through Humanistic Mathematics Education, 978 - 979 - 16353 - 7 - 0, 787-800. https://eprints.uny.ac.id/1875/1/P - 75.pdf

Subianto, J. (2013). Peran Keluarga, Sekolah, Dan Masyarakat Dalam Pembentukan Karakter Berkualitas. Edukasia: Jurnal Penelitian Pendidikan Islam, 8(2), 331-354. https://doi.org/10.21043/edukasia.v8i2.757

Zainuren. (2014). Peran Orang Tua Sebagai Pendidik dan Pendorong. Unila. http://digilib.unila.ac.id/943/2/BAB I.pdf 